\title{
ON THE PROTECTIVE COLORATION AND ATTITUDE OF LIBYTHEA CELTIS ESP.
}

\author{
BY NICHOLAS KUSNEZOW.
}

[From Horae Entomologicae, xxxv, ryoo ]

The article describes the protective coloration of the imago of Libythea celtis Esp. and its original attitude in repose. The observations were made by the author on the southern coast of the

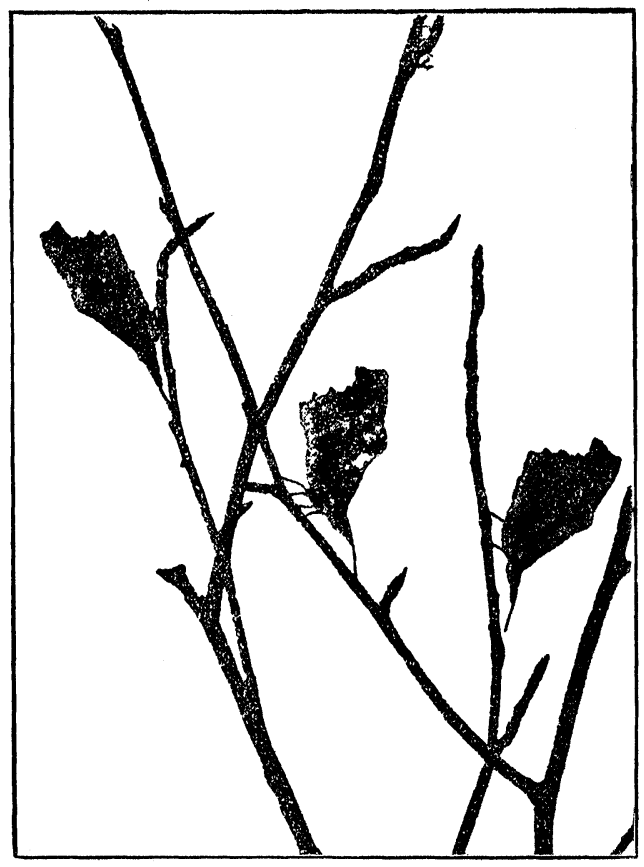

Crimea; they do not require detailed explanations, which appear in the Russian text; the appearance is clear from the subjoined figure, which is explicit enough. The butterfly in repose exactly resembles a dead leaf, just as many tropical Rhopalocera with the famous Kallima at the head. The circumstance that Libythea celtis makes use of its palpi and antennae for the simulation of a stalk of a leaf is very singular, as no tropical "leaf-shaped" butterfly does it. In this respect the example of $L$. celtis is unique. In the majority of cases the role of this stalk is borne out by various appendices of the hind wings.

The coloration completely conforms to the habits of the insect. The well known species with tailshaped appendices of the hind wings have a habit of raising the fore part of the body, applying these appendices to a stick and concealing their antennae between the fore wings; the $L$. celtis, on the contrary, inclines forwards, stretches its palpi and antennae, touching with them the leafless twig, and raises the anal angles of the hind wings.

The form of the folded wings and the presence on the underside of the hind wings of a dark median vein -observed only in the L. celtis - make the resemblance to a leaf still more complete. 
We have thus in this species a unique example of an European butterfly, which mimics the dead leaf as perfectly, and possibly even not worse, than several celebrated tropical species.

\section{SOME INSECTS OF THE HUDSONIAN ZONE IN NEW MEXICO.-IV.}

\section{HYMENOPTERA.}

(Part)

BY WILLIAM H. ASHMEAD.

Family Crabronidae.

(1) Stenocrabro cinctitarsis, new species.

8.- Length $6.5 \mathrm{~mm}$. Black, shining; the tibial spurs, the extreme apex of the first joint of the anterior tarsi and joints 2 and 3 entirely, and joints $\mathrm{I}$ to 3 of middle tarsi, yellowish-white. The clypeus at apex medially is subproduced and clothed with a dense silvery pubescence; the mandibles and the mesopectus with sparse silvery hairs. The head is quadrate, smooth above, but anteriorly it is sparsely, minutely punctate and with a median grooved line; the eyes are large and converge anteriorly; the ocelli are arranged in a triangle, the space between the margin of the eye and the lateral ocelli being greater than the space between them. Mandibles black, bidentate. The pronotum is not short and has a deep transverse impression above, the hind margin having a delicate median notch which conforms to a delicate median grooved line on the anterior half of the mesonotum; both of these sclerites are smooth and shining, although with a high power lens one can detect sparse, microscopic punctures scattered over the surface. The metathorax above is smooth, polished, with a broad median groove and an oblong area on each side of the groove; the posterior face of the metathorax is transversely regulose, the pleura striate. The wings are hyaline, with a faint fuscous tinge, the stigma and veins being brown, the stigma and costal vein dark brown; the recurrent nervure unites with the cubital cell just beyond its middle. The abdomen is a little longer than the head and thorax united, subclavate, smooth and shining, but with a high power lens, exhibits, particularly on the second and third dorsal segments and the base of the third, very fine, delicate, transverse aciculations.

Type-Cat. No. 5349, U. S. N. M.

Habitat. - Top of range between the Sapello and Pecos Rivers at an altitude of about I rooo feet. One $\delta$ specimen.

\section{Family Pompilidae.}

(2) Ceropales fraterna Smith.

Prof. Cockerell has taken one $q$ specimen. It is a species widely spread over Canada and the United States.

\section{Family Eumenidae.}

(3) Ancistrocerus sexcingulatus, new species.

8.- Length $8 \mathrm{~mm}$. Black with the head and thorax rather coarsely punctate; a broad apical band on dorsal abdominal segments $I$ to 6 , a band at apex of ventral segments 2 and 3 and a spot at hind angles of 4 and 5 , the mandibles except at apex, the clypeus entirely, a short orbital line opposite the antennae, a spot between the antennae, a dot on temples back of the eyes, the scape beneath and two or three of the following antennal joints 

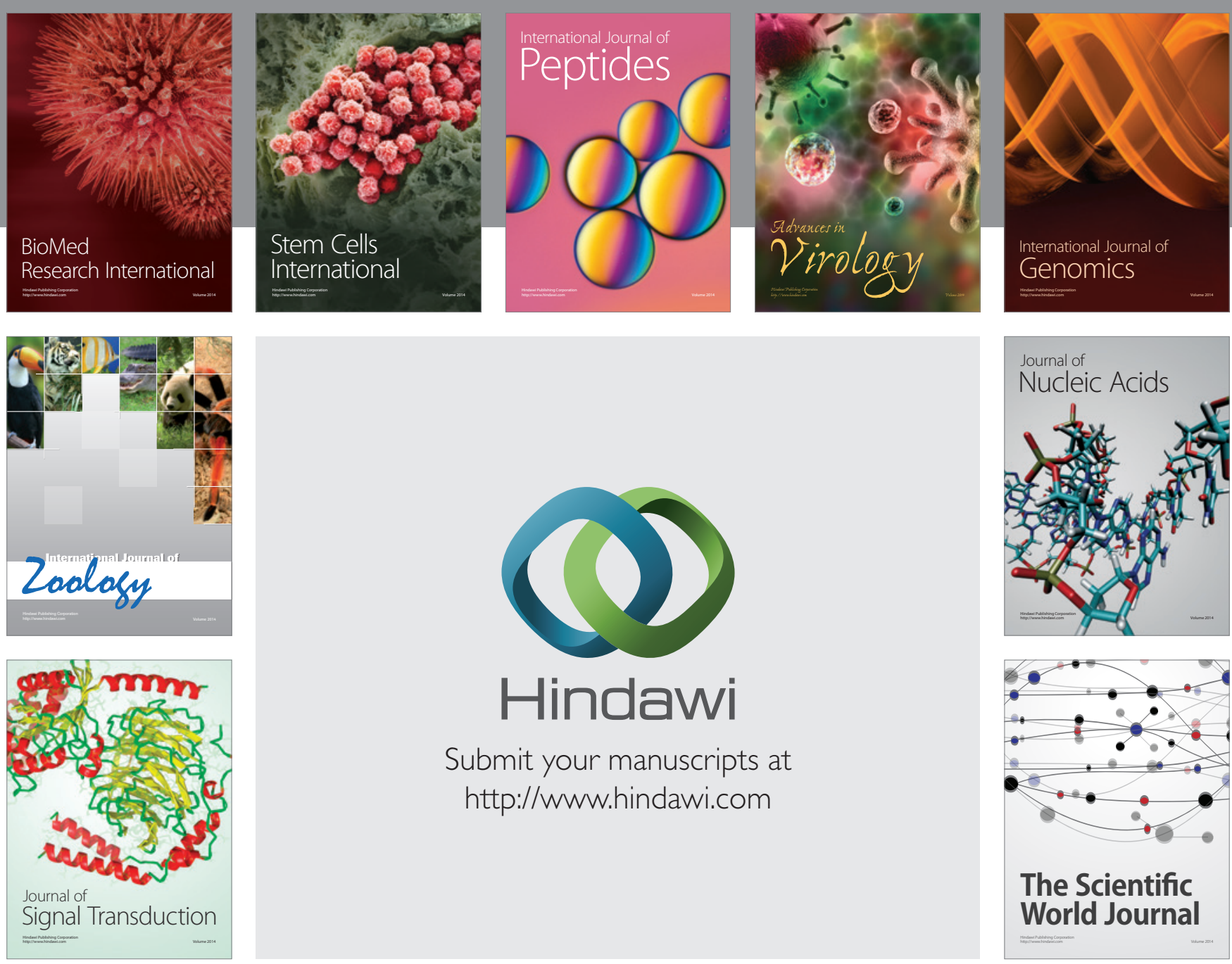

Submit your manuscripts at

http://www.hindawi.com
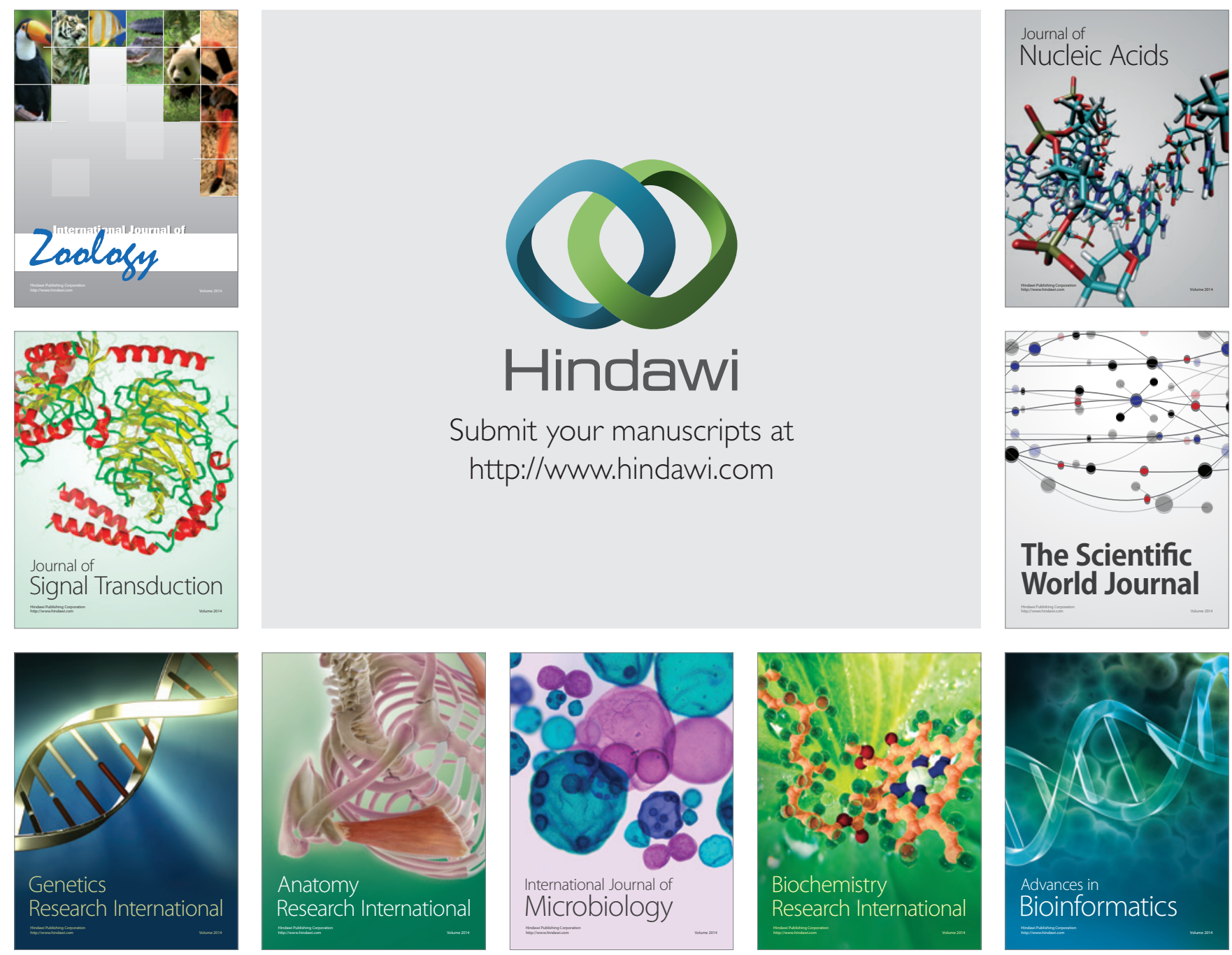

The Scientific World Journal
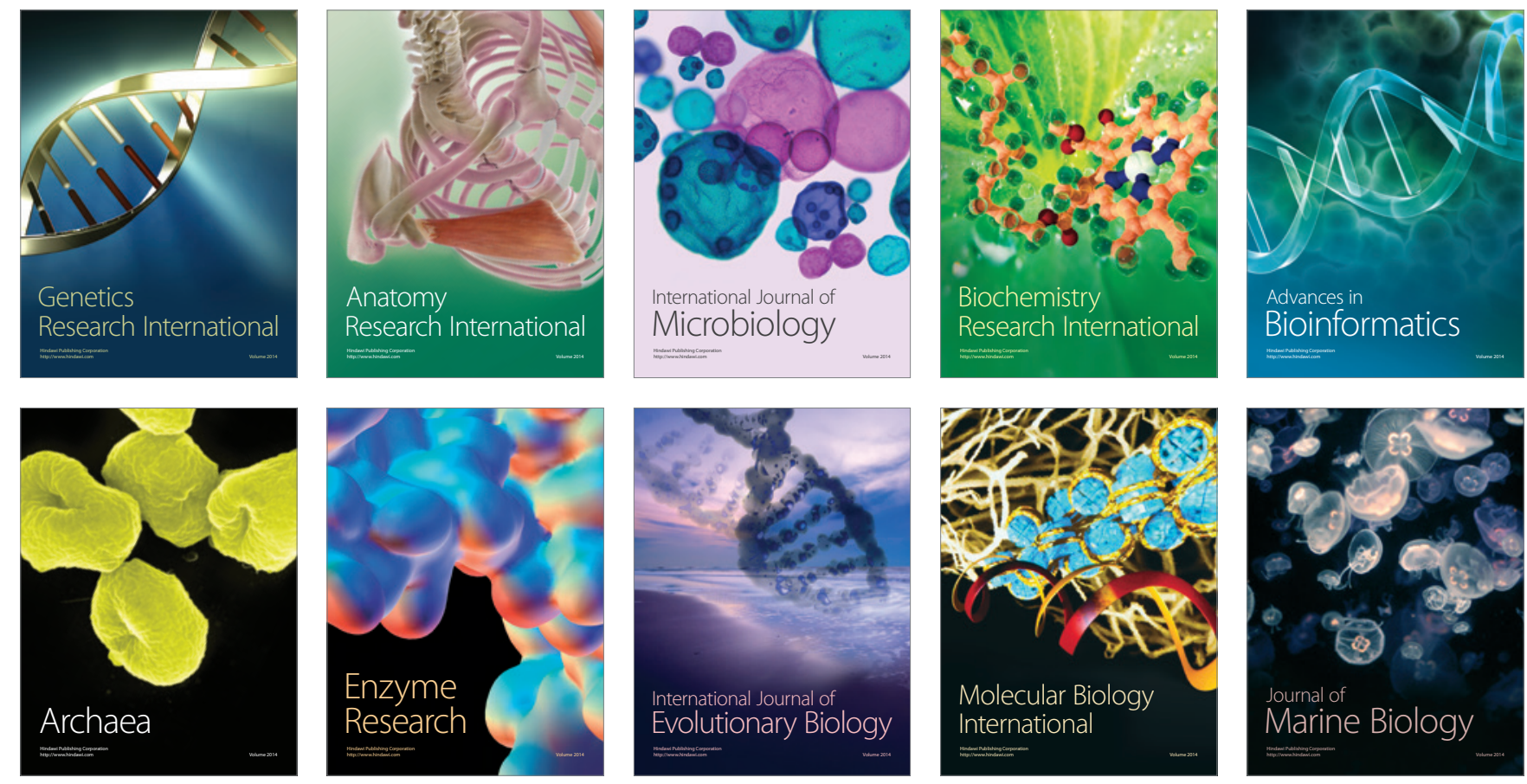